\title{
How Does the State Audit Office Promote Good Governance in Public Finances?
}

\section{Summary}

The State Audit Office of Hungary (SAO) conducts audit of more than 800 organization, (which can be public institution, municipalities, state and/or municipality owned enterprises, foundations and non-state service providers) on the efficiency, effectiveness and the regulation of the usage of public funds in accordance with good governance. In addition, SAO has an important role for analyzing and assessing the budgetary risk and shortcomings, with this action it also supports the stability of Hungary. The SAO not only supports good governance by conducting audit and providing "guide", but also leading by example and functioning as a role model for institutions using public funds.

Journal of Economic Literature (JEL) kódok: E6, F33, H6, H83

Keywords: State Audit Office of Hungary, public finance, fiscal consolidation, transparency, Fundamental Law of Hungary, Fiscal Council 


\section{INTRODUCTION}

The best indicator of a supreme controlling organisation's efficiency is improvement in the lawfulness and efficacy of using public funds. In order to achieve greater social impact, the number of audits may need to be increased. More importantly, audits should result in the correction of errors and elimination of deficiencies by the audited organisations. However, this is only the direct outcome of the reviews performed by the audit office. The direct impact achieved by the disclosure or the supreme audit organisation's reports; focused communication and consultancy based on its audits may be more significant. In the past 10 years the management of the State Audit Office of Hungary has also endeavoured to increase the number of audits in order to eliminate any blots in the audit of public funds. It has also achieved that its audits do not remain without consequences, in other words, the audited organisations take the actions required on the basis of SAO's findings and proposals. As a result of SAO's utilitarian communication activity applying modern implements, public confidence in SAO has improved and the more important findings and conclusions made in the audit office's reports and analyses have become widely known and recognised.

The State Audit Office has two powers that are not characteristic of the other supreme supervisory institutions. The first one is SAO's authorisation, aside from auditing the final accounts of the government, to compile an opinion for Parliament on the merits of the draft budget act. SAO's other special authorisation relates to the ex officio membership of SAO's president in the Fiscal Council, i.e. Hungary's independent fiscal institution. In this context, $\mathrm{SAO}$ is required by law to contribute to the Fiscal Council's work by its analyses. In order to fulfil this obligation, SAO compiles 8 to 10 analyses about the current situation of the government budget and certain fiscal policy issues. Consequently, the efficiency of SAO's work can also be judged by the extent of its ability to contribute to the creation and retention of the fiscal balance. For this reason, in this article first the Audit Office's contribution to fiscal stabilisation is presented, and then the method of SAO's contribution to good governance in the entire field of public finances is described.

\section{SUCGESSFUL FISCAL CONSOLIDATION AFTER THE GLOBAL FINANCIAL GRISIS}

SAO's efforts made in the fiscal field can be considered successful, as since 2012 the budget balance has been restored and retained. The ratio of government debt to GDP has been on the constant decrease. In order to better understand successful consolidation, it is reasonable to familiarise yourself with the circumstances that required the consolidation.

In the 1990's, transition from a socialist to a market entailed a massive economy economic recession. Transition was rendered more difficult by the huge government debt accumulated by Hungary by the end of the 1980's. However, as by the end of the 1990's, the economy had set out on a growth trajectory, the equilibrium in public 
finances had also improved, and by 2002, the government debt hardly exceeded 50 per cent of GDP.

In 2003, however, balance in the Hungarian economy started to deteriorate again. The reason was that due to the favourable world economic situation and Hungary's 2004 accession to the European Union, access to external funds became easier and cheaper over the short term. The Hungarian government of the time endeavoured to boost the economy by using external funds, and as a result of various - mainly flawed - incentives, from 2006 the rest of the economic participants also chose indebtedness to external creditors in foreign exchange. Table 1 sums up the consequences.

Table 1: Deterioration in the external and internal balance, 2003-2011 (as a percentage of GDP)

\begin{tabular}{l|c|c|c|c|c|c|c|c|c}
\hline Description & $\mathbf{2 0 0 3}$ & $\mathbf{2 0 0 4}$ & $\mathbf{2 0 0 5}$ & $\mathbf{2 0 0 6}$ & $\mathbf{2 0 0 7}$ & $\mathbf{2 0 0 8}$ & $\mathbf{2 0 0 9}$ & $\mathbf{2 0 1 0}$ & $\mathbf{2 0 1 1}$ \\
\hline $\begin{array}{l}\text { Net financing require- } \\
\text { ment }\end{array}$ & -8.3 & -9.6 & -8.0 & -6.7 & -6.5 & -5.7 & 0.9 & 2.1 & 3.3 \\
\hline $\begin{array}{l}\text { Balance of the govern- } \\
\text { ment sector }\end{array}$ & -7.1 & -6.5 & -7.8 & -9.3 & -5.0 & -3.7 & -4.5 & -4.5 & -5.4 \\
\hline Gross external debt & 57.9 & 69.9 & 80.6 & 90.4 & 102.9 & 120.9 & 142.6 & 143.9 & 148.8 \\
\hline $\begin{array}{l}\text { Gross government } \\
\text { debt }\end{array}$ & 63.1 & 58.7 & 60.5 & 64.5 & 65.5 & 71.6 & 77.8 & 80.2 & 80.5 \\
\hline
\end{tabular}

Source: Edited by the author, on the basis of data by the Central Statistical Office

Clearly, the balance of local governments exceeded the 3 per cent allowed in the EU regulations by more than double, and in 2006, more than treble, and a slight improvement started only after 2007. With the exception of 2006, the net financing requirement, i.e. the extent of using external funds, was even higher. As a result, the gross external debt rocketed, and from 2004 it was further boosted by the gross government debt and its financing from external funds. By 2008 the gross external debt had grown to double the 2003 figure, and the gross government debt exceeded the 60 per cent limit set by the EU by more than 10 percentage points in 2008 .

In the autumn of 2008 the global crisis hit Hungary in this situation. The Hungarian government needed the lifeline thrown by the European Union and the International Monetary Fund, i.e. a rapid credit facility to prevent Hungary from sinking into insolvency. As a result of additional external loans, Hungary's gross external indebtedness broke a record and approximated one-and-a-half times its GDP. Extremely painful austerity measures had to be taken to keep the government sector balance below 5 per cent, but the price paid for this was a drop in GDP by more than six per cent. Simultaneously, both businesses and the population curbed their spending, which in turn resulted in change of the net financing requirement from the negative to the positive.

Despite the help offered by international organisations, it was clear for the new Hungarian government set up in 2010 that Hungary had to consolidate its budget and stabilise and then boost its economy by its own efforts. As a result of a successful con- 
solidation, by 2012 the budget deficit had dropped and then remained permanently below 3 per cent of GDP (see Table 2). Thus, in 2013, Hungary was released from the European Union's strict fiscal supervision called Excessive Deficit Procedure.

Table 2: Improvement in the external and internal balance, 2011-2017 (as a percentage of GDP)

\begin{tabular}{l|r|r|r|r|r|r|r}
\hline Description & $\mathbf{2 0 1 1}$ & $\mathbf{2 0 1 2}$ & $\mathbf{2 0 1 3}$ & $\mathbf{2 0 1 4}$ & $\mathbf{2 0 1 5}$ & $\mathbf{2 0 1 6}$ & $\mathbf{2 0 1 7}$ \\
\hline Net financing requirement & 3.3 & 4.3 & 7.3 & 5.2 & 7.4 & 6.2 & 4.3 \\
\hline Balance of the government sector & -5.4 & -2.4 & -2.6 & -2.6 & -1.9 & -1.6 & -2.2 \\
\hline Gross external debt & 148.8 & 129.2 & 117.8 & 117.1 & 108.7 & 97.0 & 84.9 \\
\hline Gross government debt & 80.5 & 78.4 & 77.1 & 76.6 & 76.6 & 75.9 & 73.3 \\
\hline
\end{tabular}

Source: Edited by the author, on the basis of data by the Central Statistical Office

The data of the table clearly show that in 2012 a steady decrease also began in the gross government debt. Decline in the gross external debt was even faster, as household savings represented an ever increasing ratio in government debt financing. Acceleration in economic growth, which began in 2013 and approximated five per cent in 2018, had a major role in the favourable change in indicators.

\section{The State Audit Office's audits to facilitate the CONSOLIDATION OF PUBLIC FINANCES}

In 2010 Hungary's public finances compared to a tank with water leaking through several large holes. In such a situation the most important task was to focus our audits to the most critical places, revealing the causes of deficit and making proposals for its elimination. Perhaps the most significant components of this activity included the following:

- Mandatory private pension funds;

- Indebtedness of local governments;

- Management of government debt;

- Business associations in public ownership;

- Our audits and analyses of the fiscal risks involved in the monetary policy.

Audit related to mandatory private pension funds

The most striking example was provided by mandatory private pension funds. The State Audit Office thoroughly explored the topic from all angles in 2010, when the operation of guarantee fund underlying private pension funds was audited. The original purpose of the guarantee fund was to guarantee pension disbursement for the beneficiaries of pension funds should they become insolvent. If the guarantee fund is emptied, the central budget was supposed to step in and perform the liabilities. We identified minor deficiencies in the Fund's management, but the most significant finding of the audit was that it shed light on the unsustainability of the entire regime. 
In 1996 Hungary set up a pension regime essentially based on the idea that the younger generations withdrew the majority of their individual pension contributions and transferred them into private pension funds, and the budget was expected to top up the shortfall in social security revenues by ever increasing amounts in order to pay the allowances of those who had already retired. The difference, the European Commission refused to recognise as an adjustment item, increased the government deficit and the government debt at a pace accelerating year by year. To give you just a few characteristic data: the central budget used HUF 28.1 billion to support the pension insurance fund in 1998 and HUF 599.1 billion in 2009, representing more than a twenty-fold increase, and exceeding 2 per cent of GDP in 2009. The central budget contributed to the financing of retirement benefits increasingly: while back in 1998 its contribution amounted to 3.6 per cent, in 2009 it was already 21.1 per cent.

As a result of the financial crisis that began in 2008, savings in pension funds dropped by more than 21 per cent, and thus we were clearly running the risk that yield on the savings deposited in private pension funds may remain below the inflation rate during the savings period. To address to this risk, in 2009 Parliament amended the relevant act to undertake a yield guarantee, in other words, it required that if the real yield of the saving remains negative up to the establishment of the pension, then the private pension must be determined as a multiple of the deposit and the inflation rate. This decision was adopted at a moment following eleven years of nearly 6 per cent average inflation rate, while the mean nominal yield of savings hardly exceeded 1 per cent. Undoubtedly, ultimately the payment of this guarantee also required coverage from the central budget. Nevertheless, not even estimates were made of how many thousand billion forints of additional expenditure this guarantee or it would be more factual to call it a blank cheque - required of the taxpayers of the time. This financially unsustainable system had to be discontinued. This shut off the flow that tapped and drained pension contributions from the government-organised social security system. Subsequently, the budget of the Pension Insurance Fund was stabilised, and moreover, surplus was made for several years.

\section{Audits revealing local government indebtedness and its causes}

The other most critical area was the system of local governments. For this reason, aster 2011 the State Audit Office conducted comprehensive audits, first of the Local Government of Budapest, then of the cities with county rights, and then by representative sampling, it selected 62 city and town governments for audit. Finally, financial equilibrium was analysed at numerous minor local governments selected on the basis of a risk analysis. Chart 1 illustrates our comprehensive findings.

The figure shows that by the end of 2010, local governments' liability from bond issuance had increased to HUF 588 billion, nearly 25-fold, in comparison to the opening balance in 2007. By the end of 2010, their liabilities from borrowing had increased by HUF 192 billion, representing 41 per cent, on the 2007 opening balance. 
Chart 1: Local government bonds and loans, 2007-2010 (HUF billion)

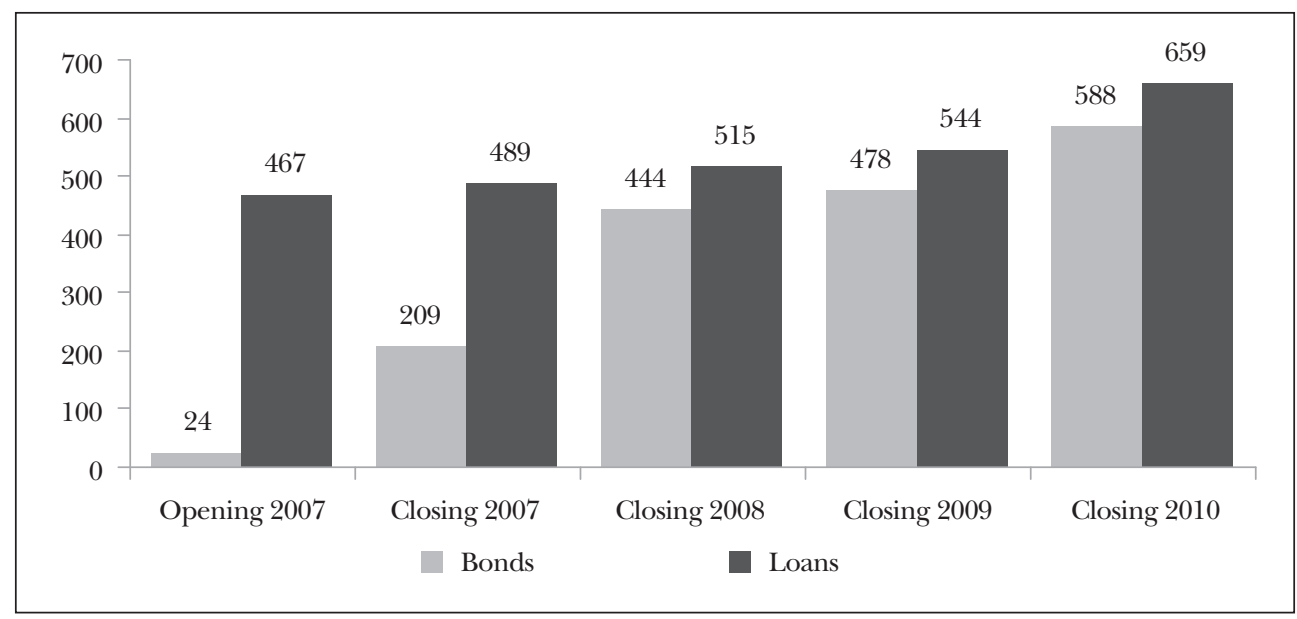

Source: SAO Report no. 1282, p. 12

In November 2011, the State Audit Office compiled a summary report of the experiences gained during local government audits and made proposals for several government actions. These were aimed at solving the grave financial situation, on the one hand, and at the prevention of the local governments' repeated indebtedness on the other. It is recalled that the local governments' debt was consolidated, and any transactions giving rise to debt were made subject to government authorisation.

After debt consolidation, the State Audit Office still keeps the audit of a wide circle of local governments on the agenda, as it wishes to prevent the individual local governments from repeatedly running into debt. Thorough audit is required precisely because after the prevention of overt indebtedness, poorly managed local governments have been maintaining their solvency temporarily in implicit forms of indebtedness (e.g. the late payment of supplier claims or borrowing through their business associations.

\section{The audit of government debt management}

Government debt management was the third critical area we needed to urgently audit. Our report about the audit of the debts and long-term commitments of the central sub-system in public finances, published in August 2012, identified gross shortcomings. Chart 2 gives a good illustration of the situation that evolved.

In the audited period increase in foreign exchange debt from 28.0 per cent in 2006 to 44.7 per cent in 2009 was an essential risk factor. In 2010 the risk realised by a massive forint weakening, and increased government debt by HUF 1656.7 billion.

SAO's audit found that the cost and risk management model developed in 2004 for the purposes of debt management had not undergone either internal development, or an audit or a content review. This model did not manage the average remaining maturity of HUF and FX debts, the impact of change in the yield curve on debt man- 


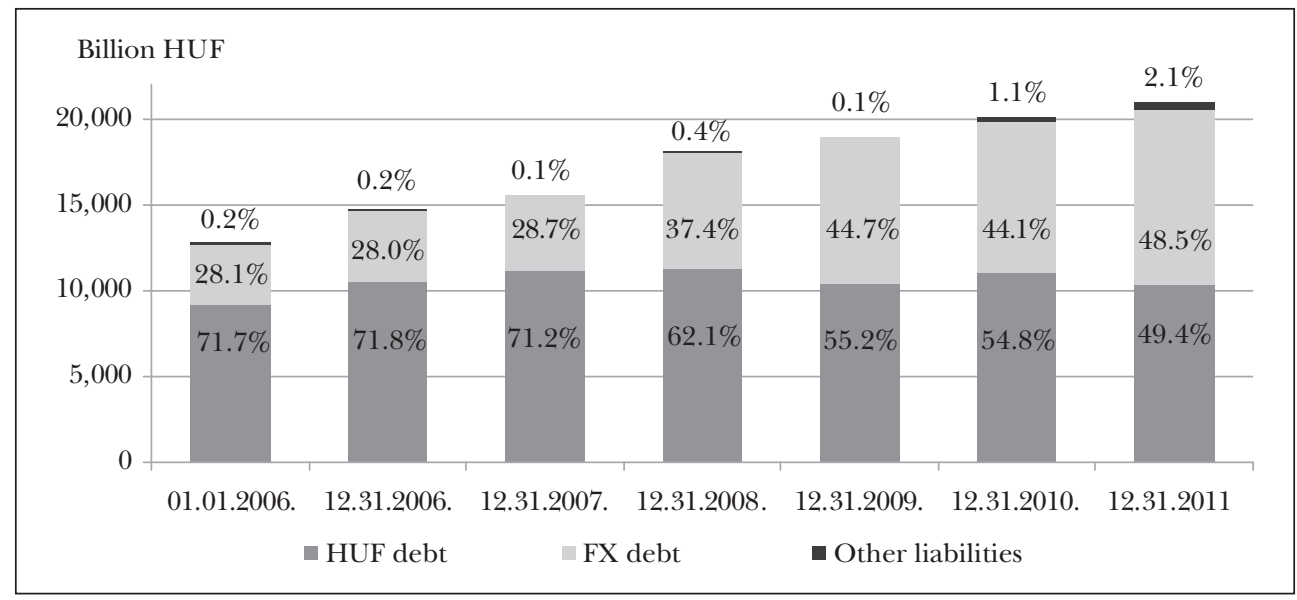

Source: SAO Report no. 1294, p. 17

agement costs, the market stress situations and the risk involved in credit rating. Államadósság-kezelố Központ Zrt. (the government debt management centre) had failed to assess and evaluate the costs and effectiveness of the individual financial and financing operations. SAO recommended that the Minister for the National Economy should take action to review the developed cost and risk management model and to elaborate an evaluation system in support of the cost efficiency of the debt management activity in order to monitor and reduce debt financing costs.

We also identified heavy future burdens during the audit of long-term liabilities, as shown in Chart 3.

It is easy to read from the figure that as a result of motorway concessions and PPP projects, the Hungarian budget incurred liabilities in the amount of HUF 150 billion payable by 2027, and amount of these commitments will exceed HUF 100 billion even in 2030. For this reason, SAO analysed the implementation of projects in a PPP scheme in the framework of several audits. It was established that these projects were generally overpriced, and instead of the risk sharing expected of a PPP scheme, the government remained the only party to assume the related risks. SAO requested reviews of the PPP contracts and the establishment of liability.

SAO audited government debt management every year in the framework of its audit of the annual accounts, and then in 2015, it repeated the comprehensive audit. It can be established that in the past few years the exchange rate risk of the government debt has considerably decreased as by the end of 2016 the ratio of FX debt to the total government debt had dropped to 24.6 per cent, nearly half of the corresponding figure recorded at the end of 2011. This development is illustrated in Chart 4. 


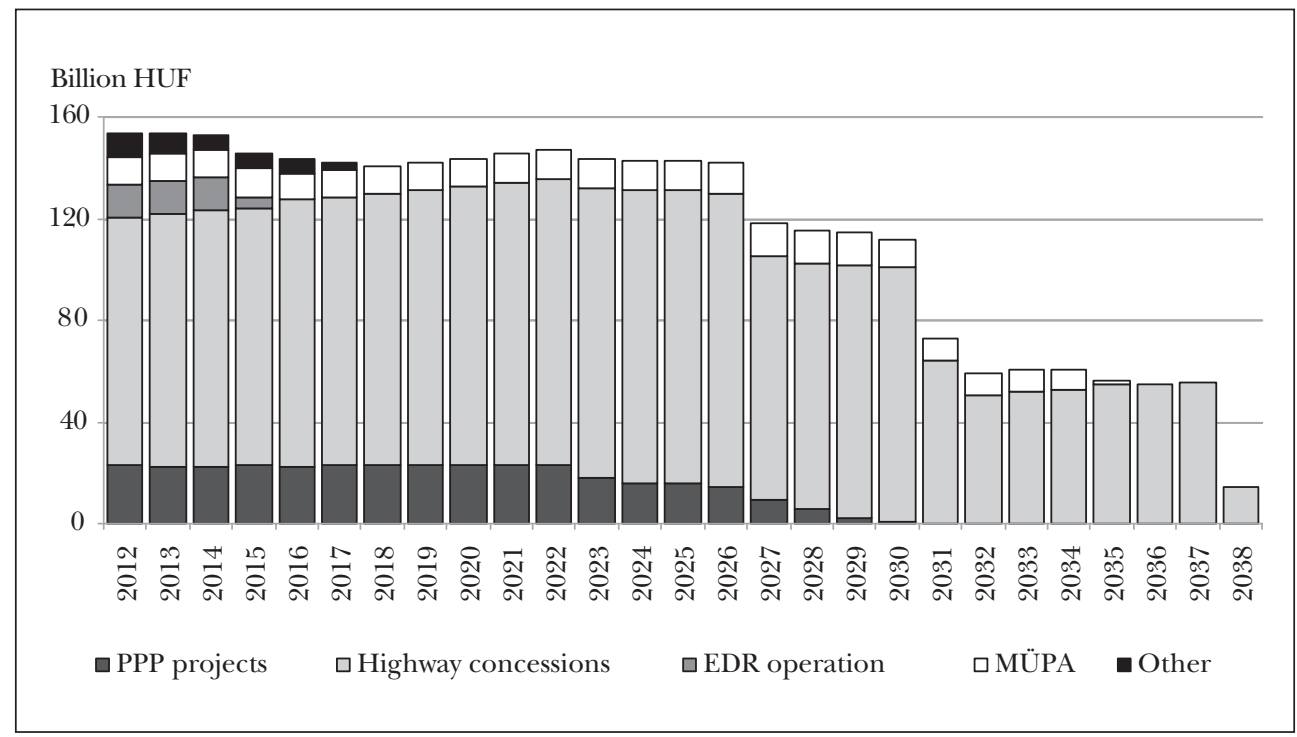

Source: SAO Report no. 1294, p. 25

On the Audit on the Debt of the Central Subsystem of Public Finances and its Commitments for Periods Exceeding one Year.) State Audit Office of Hungary, August 2012 (Report No. 1294)

Chart 4: FX debt to the gross government debt

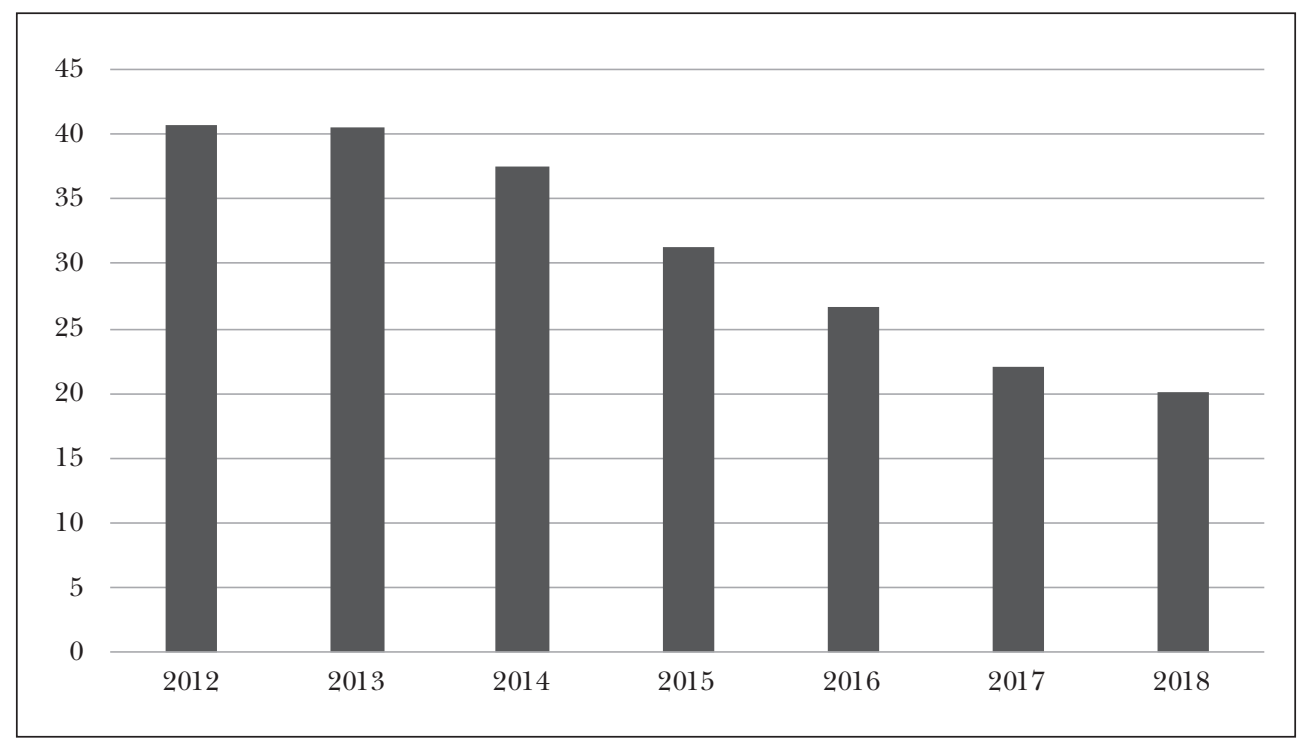

Source: Edited by the author, on the basis of data by AKK Zrt. 


\section{László Domokos: How Does the State Audit Office Promote Good Governance...}

In addition to local governments and the central budget, indebtedness in foreign exchange also affected society at large. The actions taken to help them cost hundreds of millions of forints and/or resulted in losses in revenues for the central budget. SAO verified the implementation of these measures in the framework of an audit of the annual budget accounts. SAO separately audited Nemzeti Eszközkezeló Zrt.'s (the national asset manager's) safeguarding of assets and business management between 2011 and 2014, and found them compliant with the relevant regulations. This was instrumental in ensuring housing for the families in the worst debt trap.

\section{Analysis of the fiscal risks involved in monetary policy}

As a result of indebtedness in foreign exchange, commercial banks' liquidity measured in HUF increased significantly, and they deposited such funds with the National Bank of Hungary, which paid high interest on them. As SAO is not authorised to audit monetary policy, it called the attention to the fiscal risks of the monetary policy of the time in an analysis (Pulay et al., 2013). In this analysis we demonstrated the rapid rise in interest burdens, as plotted in Table 3 .

Table 3: Amounts paid by the National Bank of Hungary (MNB) for monetary assets (2007-2011)

\begin{tabular}{l|r|r|r|r|r|c}
\hline \multirow{2}{*}{ Description of the monetary asset } & \multicolumn{6}{|c}{ (Net) interest paid by MNB (HUF billion) } \\
\cline { 2 - 7 } & $\mathbf{2 0 0 7}$ & $\mathbf{2 0 0 8}$ & $\mathbf{2 0 0 9}$ & $\mathbf{2 0 1 0}$ & $\mathbf{2 0 1 1}$ & 5 years, total \\
\hline Minimum reserve requirements & 49.6 & 60.9 & 29.4 & 20.0 & 54.6 & 214.5 \\
\hline Two-week bond & 75.1 & 71.4 & 226.7 & 213.8 & 255.2 & 842.2 \\
\hline Overnight deposit & 0.5 & 12.1 & 24.8 & 4.8 & 8.2 & 50.4 \\
\hline Total & 125.2 & 144.4 & 280.9 & 238.6 & 318.0 & 1107.1 \\
\hline
\end{tabular}

Source: Edited by the author, on the basis of data by the National Bank of Hungary

The analysis raised the necessity of regulatory changes that would lower the interest payable by the National Bank of Hungary, and simultaneously channel part of the liquid funds for financing the government debt. From 2013, the central bank's new management found the monetary policy actions that led in the direction we recommended.

\section{Audit of other organisations classified into the government sector}

SAO audits an increasing number of business associations in state and local government ownership, as according to the regulations of the European Union, part of them fall in the government sector and thus their debts increase government debt. In the case of other organisations included in the government sector (i.e. not included in public finances), we can speak of rising numbers, as an increasing number or organisations are found that should be classified in the public finance sector based on the 
features of their business management. Simultaneously with rise in their number, the debt they represent is also on the increase, and this is further increased by a rise in the debt of the individual business associations.

Table 4: Debts of other organisations classified into the government sector, 2010-2016

\begin{tabular}{l|c|c|c|c|c|c|c}
\hline Year & $\mathbf{2 0 1 0}$ & $\mathbf{2 0 1 1}$ & $\mathbf{2 0 1 2}$ & $\mathbf{2 0 1 3}$ & $\mathbf{2 0 1 4}$ & $\mathbf{2 0 1 5}$ & $\mathbf{2 0 1 6}$ \\
\hline Debt, total (HUF billion) & 70.3 & 62.5 & 123.5 & 154.9 & 190 & 319 & 332.6 \\
\hline
\end{tabular}

Source: Data by the Ministry for the National Economy

The data clearly show that these are no insignificant amounts, as in 2016 the aggregate debt portfolio already exceeded 1 per cent of GDP. SAO monitors this process and in the course of its other audits of entities classified in the government sector, it assigns priority to exploring whether or not the particular audited business association had any transaction generating government debt and if it was duly authorised. It was high time we inspected these matters, as we also found gross deficiencies in this field. For example, there was a business organisation which was not aware of the fact that it had been classified into the government sector. Some companies were not aware of the serious consequences of such transactions, e.g. the obligation to seek authorisation for loans and to build an information retrieval system or a more stringent internal control system.

Another important criterion applied during the audit of business associations was the how public utility companies could react to the challenge posed by mandatory reductions in utility bills. In numerous cases we established that public functions had not been separated from other functions; the fees charged for public services were not underpinned by cost accounting calculations; and deficient management coupled with unregulated asset management posed a risk. Consequently, a more accurate accounting and a more efficient business management still offer considerable opportunities. In business management and operation we identified numerous risks that were traceable to regulatory gaps in the exercise of rights by the corporate management and by the owners.

Our audits of business associations in public ownership confirmed that there was a need to renew the state management. The Government accepted our recommendations and integrated them in the relevant statutory regulations at several points.

\section{Opinion on the merits of the draft budget act}

In order to give an opinion on the grounding of the budget appropriations, the State Audit Office developed and published a method based on solid foundations. With the help of this method, SAO can quantify the risk of underperforming or overperforming the planned appropriations, and then compares the aggregated risks with the planned budget reserves. If the latter provide coverage for the management of reasonably arising risks, it does not consider the fulfilment of the debt rule as prob- 
lematic, and if the reserves are insufficient, it motions for their increase. Why is this important? The aim of this method is to bring reserve maintenance into the focus of the opinion about the draft budget act. This method can ensure sufficient reserves simultaneously with predictability and flexibility in fiscal management. Reserves create the opportunity for the elimination of interim tightening measures (taxes and blockings), in other words, wartime budgeting.

In my opinion, the most significant outcome of the State Audit Office's initiatives is that in recent years a multi-tier provisioning system has evolved in budgeting. In addition to the general reserve that covers contingent expenses, currently termed as an "appropriation for special government actions", the County Protection Fund was also set up primarily to manage macro-economic risks. It has become general practice also for budgetary chapters to plan a reserve for the management of risks at a chapter level. However, I consider the appearance of "implicit reserves" as the most momentous development. As far as I am aware, the Hungarian State Audit Office was the first ever to coin this term in its analysis compiled for the Fiscal Council.

What is an implicit reserve? Both deficit and debt have an implicit reserve. In the case of deficit, the implicit reserve is the difference between the limit set in the relevant budget regulation and the deficit target. According to the European Union's regulation, the government sector deficit may not exceed 3 per cent of GDP. Thus if the government targets a 2.4 per cent deficit, the implicit reserve is 0.6 per cent. In the case of debt, the implicit reserve is the difference between the limit set in the regulation on government debt and the targeted debt indicator. Since 2013 the draft budget acts have always targeted more favourable deficits and debt indicators than allowed. Consequently, the draft act included considerable implicit reserves. Since 2013 this system of reserves has actually eliminated the need to implement interim adjustments. This is one of the most important achievements of fiscal consolidation, as it created the conditions for methodical budget management by fiscal units, so that they can use public funds lawfully, purposefully and efficiently.

The other important factor that contributed to fiscal stabilisation was the stabilisation of tax revenues. The fact that actual tax revenues decreasingly fell short of the plans, and in fact, in 2015 the plan was already considerably exceeded was major contribution to fiscal consolidation. Chart 5 gives a good illustration of the trend of improvement.

The figure shows that between 2010 and 2013 tax revenues fell more than a hundred billion forints short of target. The turning point came in 2014, when in the aggregate, tax revenues were collected slightly in excess of the target. And in 2015, payments considerably exceeded the target in each of the three types of taxes. The taxes and tax-type revenues collected in the amount of HUF 8000 billion in 2015 exceeded the original target by HUF 469 million (i.e. 6.2\%).

There are various additional opportunities to increase the efficiency of tax collection and the legitimisation of the shadow economy. During its audits of the National Tax and Customs Authority ("Tax Authority"), the State Audit Office also identified several gross deficiencies - for example, during the audit of tax benefits, in risk management, 
Chart 5: Difference between statutory appropriations and actual performances (HUF billion)

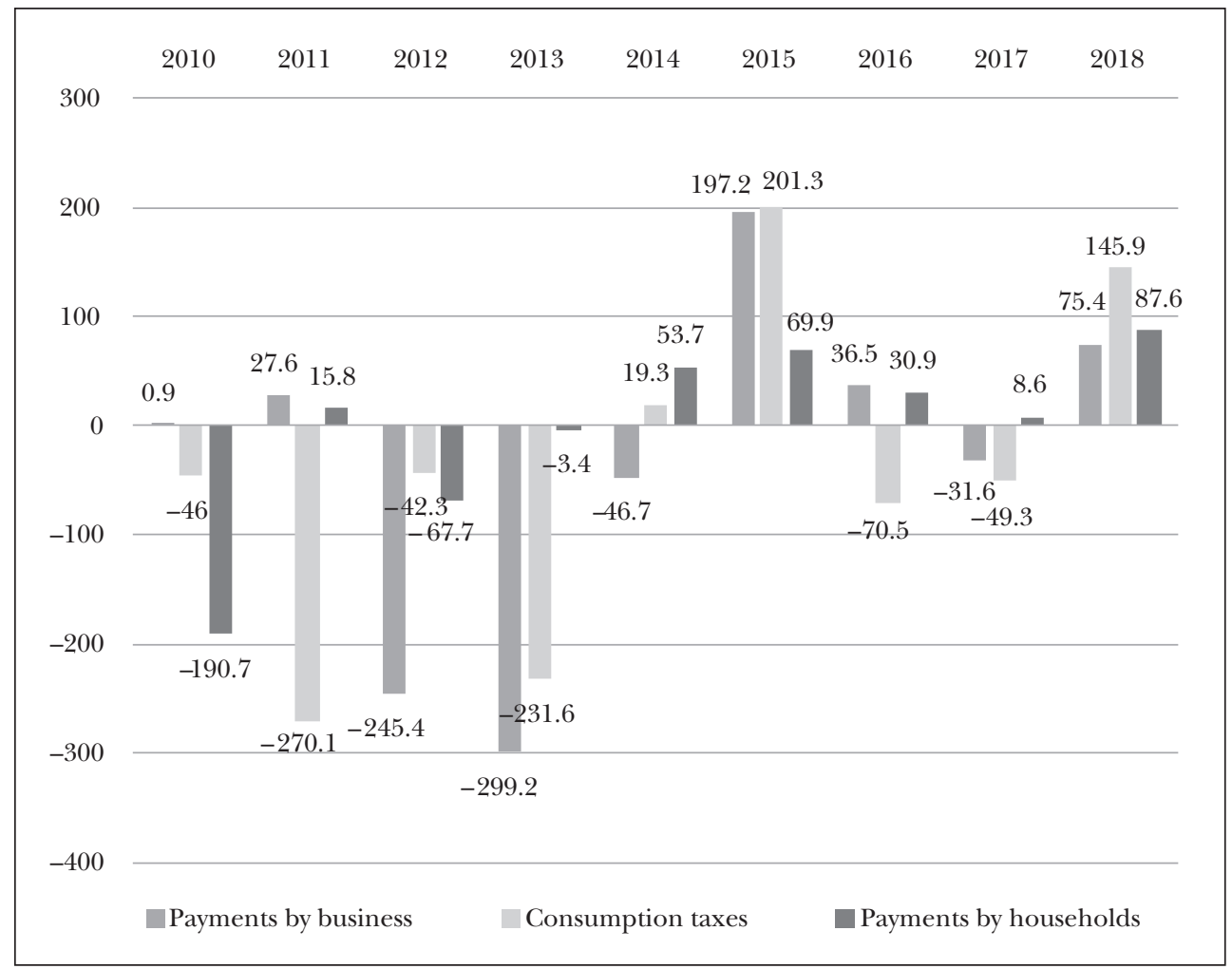

Source: Author's own, based on data from the Ministry of the National Economy

and in the prevention of arrear accumulation -, which may considerably increase the amount of actually collected tax revenues. Based on SAO's audit findings, the management of the Tax Authority took numerous actions that contributed to the improvement in the efficiency of tax collection.

However, improvement in the efficiency of tax collection is not an end in itself; rather it is a means of improving the competitiveness of the economy through cutting tax rates. This was why SAO urged the "sustainable legitimisation" of the shadow economy. In essence this means that in the form of lower tax rates or targeted benefits, the state lets the taxpayers have the surpluses obtained from the legitimisation of the shadow economy, and due to lower tax rates, reduction of the underground economy may continue. The tax policy actions taken in recent years reflect this intention.

\section{TRANSPARENCY ON A MACRO-ECONOMIC \\ AND MICRO-ECONOMIC LEVEL}

Article 39 (2) of Hungary's Fundamental Law requires transparency in general, when it stipulates that "Every organisation managing public funds shall be obliged to pub- 


\section{László Domokos: How Does the State Audit Office Promote Good Governance...}

licly account for its management of public funds. Public funds and national assets shall be managed according to the principles of transparency and the purity of public life. Data relating to public funds and national assets shall be data of public interest." The principle of integrity in public life means the use of public funds according to their intended purpose, free of corruption and fraud.

The expressions "macro-prudential" and "micro-prudential" supervision are used in relation to finances and the institutions constituting the financial intermediary system. Currently, both are performed by the National Bank of Hungary. The central bank is required to supervise the correct management of one-off risks for financial intermediary institutions, while in the framework of macro-prudential supervision, it monitors the systemic risks jeopardising the financial system and when required, it motions for actions. A prudent, in other words, forward-looking conduct refraining from the assumption of unreasonable risks and its supervision are justified because financial intermediaries invest their depositors' money and not their own, and if they make a loss or have liquidity problems, they put their depositors in a difficult situation.

Similarly, businesses using public funds spend money that does not belong to them as it has been collected by the government from citizens for financing public functions. For this reason it is reasonable to apply more stringent rules to institutions using public funds than to those using their own money. As prudent operation is a fundamental condition for financial intermediaries, so the organisations managing public funds are required, as a minimum set in the above-referenced provision of the Fundamental Law to act transparently and free of corruption. This must be enforced both at a macro-economic (government) and at a micro-economic (institutional) level. The State Audit Office is responsible for verifying whether or not the requirements of transparency and the integrity in public life are complied with both on the macroeconomic and on the micro-economic level. The latter requirement primarily means operation and management without corruption.

The two most significant areas of macro-economic control include the evaluation of the draft central budget act and the audit of the government's report about the implementation of the central budget, in other words, the annual accounts. The former has already been discussed in detail. The audit of annual accounts is the most important duty of every audit office. The predecessor of today's State Audit Office was established in 1870 to audit the annual accounts of the Hungarian government budget, independent within the Austro-Hungarian Monarchy. Currently this remains the kind of audit that requires the largest capacity of the audit office. The State Audit Office perceived it as a professional challenge to check the reliability of a report of several thousands of pages. Previously, the SAO management opted to scrutinise the financial accounts of a different institutions every year in addition to the annual audit of the major items. SAO had been able to develop and apply the method suitable for giving an evaluation of the entire report on duly substantiated grounds every year by the time of the audit of the 2015 financial accounts.

On a micro-economic level the most challenging factor is the large number of organisations using public funds and public assets. This circle includes about twenty 
thousand organisations, from budgetary units through business associations in public ownership to government organisations attending to public functions (e.g. institutions of foundations and churches). With the traditional methods it would take decades for the 500-strong SAO to audit so many organisations. For this reason, the audit of all the twenty thousand organisations by SAO within four or five years cannot be set as a reasonable objective It was, however, important that every organisation financed from public funds should manage its business aware of the fact that the State Audit Office may audit its activity and accounts at any time. In order to accomplish this objective, the number of organisations audited in a year had to increase from around 200 before 2010 above 800 , and the public sector should not have any "blots" never subject to an audit by the Office. This was the purpose, for instance, of the audit of minority governments and public bodies (chambers), never previously audited by SAO, and then of the comprehensive audit of business associations in public ownership, which was made legally possible for the Audit Office after 2011. 2017 saw the start of audits at a wide circle of organisations not maintained by the government but providing public services. Developments in the number of organisations audited by SAO are depicted in Table 5 .

Table 5: The audit reports published annually by the State Audit Office and the number of organisations audited between 2011 and 2016

\begin{tabular}{l|c|c|c|c|c|c|c|c}
\hline & $\mathbf{2 0 1 1}$ & $\mathbf{2 0 1 2}$ & $\mathbf{2 0 1 3}$ & $\mathbf{2 0 1 4}$ & $\mathbf{2 0 1 5}$ & $\mathbf{2 0 1 6}$ & $\mathbf{2 0 1 7}$ & $\mathbf{2 0 1 8}$ \\
\hline Number of audited reports & 71 & 112 & 194 & 233 & 221 & 260 & 251 & 323 \\
\hline Number of audited organisations & 387 & 499 & 569 & 966 & 717 & 740 & 874 & 806 \\
\hline
\end{tabular}

Source: Author's own, based on data from the annual reports of the State Audit Office

The last line in the table reveals that by 2013 we had managed to increase the number of audited organisations above 500, which required raising the audits to nearly 200. (A report is made of every audit, but several organisations may be inspected in the framework of an audit.) The latter was primarily enabled by the adoption of the method we call thematic group audits. In essence this means that SAO audits one or two high-priority areas in the activities (e.g. the deployment and operation of internal controls, and asset management) performed by organisations of similar types (e.g. central budget units, business associations in local government ownership, forestry holdings and museums). This proved useful not only because 10 to 30 organisations could be audited on the basis of a single professional programme, but also because the thematic group audits revealed the typical deficiencies in the individual areas. Consequently, the published reports also served as guidance in the correction of the errors for the organisations of the area that had not been audited. In order to better capitalise on this utilisation opportunity, SAO compiled a report of its experienced gained during numerous thematic group audits, and published them. Moreover, in several cases they were presented in the framework of conferences on "best practices". 


\section{László Domokos: How Does the State Audit Office Promote Good Governance...}

The number of audited organisations peaked in 2014. We do not aim at increasing figures at any cost, as with the given capacity, this would jeopardise the quality of audits. However, the 2015-2018 data suggest that SAO can sustainably conduct more than 200 audits per year, including the audit of 700 to 900 organisations. Currently, we are working on new audit methods that would enable further increase in the number of audited organisations. The essence of the concept is that in the first audit module, risks would be identified and additional audit modules would only be conducted in the case of companies found to be risky.

Following approval of the new law on the State Audit Office, audits focused on internal control, the accounting regime, asset management, the financial position and business management. These topics are all closely related to improvement in the business management by public sector organisations. However, simultaneous macroeconomic improvement has also remained a significant objective: The number of audits focussed on support to good state governance and on improvement in economic competitiveness has exceeded two hundred since 2015.

\section{FACILITATING THE OPERATION OF A WELL GOVERNED STATE IN} THE FISCAL FIELD

One of the most innovative provisions in the act newly adopted in 2011 about the State Audit Office stipulates that "based on its audit experience, the State Audit Office of Hungary assists Parliament, its committees and the work of the audited entities, thus facilitating well-governed state operations." ${ }^{1}$ In relation to this the first thing to be reasonably determined is the direction SAO helps government organisations to follow. Since the promulgation of Hungary's Fundamental Law, i.e. 25 April 2011, this is clear, as the Fundamental Law, which has an independent chapter on public finances for the first time ever in Hungary's history, has set the direction of the management of public funds. Above all, the provision on government debt set out in Article 36 (4) and (5) should be highlighted. Whereby:

“(4) Parliament may not adopt an Act on the central budget as a result of which state debt would exceed half of the Gross Domestic Product.

(5) As long as state debt exceeds half of the Gross Domestic Product, Parliament may only adopt an Act on the central budget which provides for state debt reduction in proportion to the Gross Domestic Product."

As Hungary's government debt still considerably exceeds 50 per cent of the gross domestic product (GDP), the current task is to continuously improve the government debt-to-GDP ratio. With a view to this, it considers the promotion of compliance with the government debt requirement as its No. 1 priority in the course of its audits and consultancy. In the case of audits this means that the areas with a business management and operation that have direct impact on government debt are given priority during selection, and in their case the audit focuses, among others, exactly on revealing impact on the government debt and the compliance and reliability of data in this respect. Particular consideration is given to the impact on government debt during 
topic selection, but the audits also include the denominator of the debt ratio, i.e. the factors determining GDP developments. Examples include SAO's studies analysing the encouragement of research, development and innovation, and the financial role undertaken by the state (Pulay et al., 2015; 2016; 2017).

The other provisions in the chapter on public finances in the Fundamental Law further clarify the concept of good state governance in the fiscal field. Article 37 (1) of the Fundamental Law stipulates that " $[\mathrm{t}]$ he Government shall be obliged to implement the central budget in a lawful and expedient manner, with efficient management of public funds and by ensuring transparency." This is in agreement with Article 43 (1) of the Fundamental Law, which lists SAO's most significant tasks as follows: "Acting within its functions laid down in an Act, the State Audit Office shall audit the implementation of the central budget, the management of public finances, the use of funds from public finances and the management of national assets. The State Audit Office shall carry out its audits according to the criteria of lawfulness, expediency and efficiency." It follows from the co-occurrence of the two referenced provisions in the Fundamental Law that a well-functioning state manages public funds lawfully, expediently, efficiently and transparently, and this is guaranteed exactly by SAO's audit activity, which may review compliance, reasonableness and efficiency, and may also contribute to transparency as its reports are public.

In addition to audits, SAO also supports the operation of a well governed state by its analyses laying the foundations for its consultancy. Its regulatory basis was laid down in Article 5 (13) of the Act on the State Audit Office, which provides the following: "Within its competence, the State Audit Office of Hungary may prepare analyses and studies. In connection with the tasks of the President laid down in subsection 13(2)1), the State Audit Office of Hungary prepares analyses and studies and by the provision thereof it assists the Fiscal Council with the performance of its tasks." The referenced Article 13 (2) 1) stipulates that the President of SAO "acting as a member of the Fiscal Council, shall perform the tasks assigned to them to this end in a separate act."

This co-occurrence of statutory provisions sheds light on the fact that SAO has been assigned an extremely important responsibility and powers to indicate fiscal risks by the appointment of its president to act ex officio as a member of the Fiscal Council (hereinafter: "Council"). This is because through the president's membership, the entire organisation is obliged to compile analyses and studies that help the Council in its attendance to its duties. If we continue reading the chain of provisions in the referenced act, it can be established that these analyses must be based on SAO's audit experiences, but at least they must relate to SAO's functions. It is fair to say that in order to implement the above-referenced provisions of the SAO Act, SAO had to create a new genre of analysis. These are fundamentally characterised by their link to SAO's audit activity and facilitate the operation of good state governance in the fiscal field.

One should also understand that with the establishment of this right and obligation, SAO's opportunities to indicate fiscal risks and to motion for the elimination of shortfalls have doubled. On the one hand, since SAO's re-establishment in 1990, year 
after year it has given its opinion on the draft budget act submitted to Parliament. It substantiates its opinion by an audit conducted with a special method. (SAO displays the methodology renewed in 2014 and its supplements on its website.) $)^{2}$ In addition, every year it audits the final accounts. On the other, with its analysis SAO contributes to the Council's work related to opining the budget.

The Councils gives its opinion twice during the elaboration and approval of the budget. Firstly, it gives an opinion on the draft budget act, in other words, the version that has already been discussed and reconciled by the various ministries, but has not yet been submitted by the Government to Parliament. Thus the Council has the opportunity to call the Government's attention to the risks related to the planned budget before the final decision. Secondly, the Council gives its opinion on the draft budget act before it is put to the vote, after incorporation of the approved amendments proposed by the Members of Parliament.

This evaluation represents a highly important progress in comparison to the previous regulation, which did not require an organisation independent of the Government to give its opinion on the draft act amended by the proposals of the Members of Parliament, and therefore it could (and actually did) happen that the approved act involved considerably higher risks than the version submitted by the Government. Among others the reason for this is that the Members of Parliament drafted proposals to increase expenses in good faith, however, coverage was withdrawn from reserves or overstraining the target revenue. In order to preclude this risk, in addition to its right to report, the Council was granted the right of veto: Parliament is only allowed to approve the draft act if the latter complies with the debt rule, in other words, if as a result of the expected deficit the government debt increases less than GDP at current price, and consequently, the government debt improves. If this condition is not met, the government must make amending proposals and pass them through Parliament until the expected deficit is reduced to the level required for meeting the debt ratio.

Another stride included the fact that in addition to the approval of the original budget, the Council also has the above-mentioned powers during the approval of the draft act on the interim amendment of the budget act.

In addition to the evaluation of the various versions of the draft budget acts, once in six months the Council also gives its opinion on the progress made in the implementation of the act on the central budget and on the developments expected in government debt. In addition, it may give an opinion on

- The draft acts containing the amendments required for laying the basis for the provisions of the draft act on the central budget, including the draft acts that specify public dues.

- Any issue related to the planning and implementation of the central budget and to other ways of using public funds.

This broad evaluation function of the Council also expands the scope of topics analysed by SAO, since pursuant to the above-referenced statutory provision, SAO assists the Council in the performance of its functions by analyses and studies. 
It is important to note that SAO's analyses are based primarily on its on audit findings, although naturally, statistical data and literature findings are also processed in them. It should be highlighted that the analyses prepared for the Council to promote budget evaluation are nearly completely based on audit evidences collected and processed during SAO audits, and as such, they are more reliable than any other reported statistical data or academic estimate. Previously, SAO had also substantiated its opinion on the draft budget act by audits. In order to fulfil its function in the Fiscal Council, it has extended its audit performed in support of budget evaluation in two directions: it begins audit earlier and finishes it later. Earlier beginning enables it to collect audit evidences for the analysis of the draft budget act. At the end of the extended audit, on the other hand, it checks whether or not the ministry in charge of public finances has substantiated the decisions in support of amending motions made in the Government's name by the required calculations and impact analyses. The audit enables SAO to be satisfied that the conditions of the implementation of the amending motions (e.g. an IT development serving the legitimisation of the economy) are in place. The Council can only take a stand in the question whether or not the deficit exceeds the level required for compliance with the government debt rule on the basis of factual evidence. The fundamental factor in exercising veto is the reasonableness of the budget appropriations, as the numerical information in the draft act waiting for a vote formally obviously always meet the requirements arising from the government debt rule.

This new function of SAO is also important for good state governance because SAO regularly conducts audits in relation to the individual budget appropriations. For example, SAO obtains information that is essential for budget evaluation during its audits of the National Tax and Customs Administration's tax revenue appropriations and the Government Debt Management Agency's debt management appropriations. This information is regularly incorporated in the analyses compiled by SAO to support the Council's work and also sent to the heads of the competent government organisations.

\section{SUMMARY CONCLUSION}

The 2008-2009 financial and economic crisis undermined sustainable cooperation between the countries that follow an economic policy that is neoliberal in terms of the fundamental welfare state expectations. The previous concept of the state playing a rather passive supervisor, or a kind of a "watchman", emphasis in government action was shifted to the proactive, crisis managing role of the state in the provision of sustainable development. This paradigm change was characterised by a series of government action plans. Increasing central bank intervention in the field of monetary policy was followed by actions falling within the scope of fiscal policy implements, e.g. extensive reorganisation projects to support the consolidation of the financial intermediary system, companies employing large numbers of people and the financial position of indebted households.

The more proactive involvement of the state also had a significant impact on the activities of the supreme supervisory organisations. In contrast to "watchman" organisations, the public expectation that they should have a kind of a "steering" and guiding 
function was increasingly voiced. Simultaneously, demand also increased for step-up in audits and for extending the period and expanding the areas subject to audit. In addition to subsequent, or ex post, audits, considered as the basic type, ex ante activities also appeared in the form of analyses, consultancy, risk analyses and studies to lay foundations.

A proactive state also galvanises action by the supreme supervisory organisation urging it to become more engaged than previously in order to support good governance, and to contribute to the creation of a sustainable welfare state and thus to improvement in the life and security of citizens through the expansion of its activity and functions. The audit office should become a model institution and its exemplary operation should inspire the transformation of other public sector institutions. In summary: a proactive state requires a proactive audit office.

\section{Notes}

1 Article 1 (4) of the Act on the State Audit Office.

2 Módszertani útmutató a Magyarország központi költségvetésérôl szóló törvényjavaslat véleményezését megalapozó ellenôrzéshez [Methodological guide to the audit providing a basis for an opinion on the draft budget act of Hungary, and the supplements applicable to the 2015 and 2016 audits]. https://asz. $\mathrm{hu} / \mathrm{hu} /$ egyeb-utmutatok.

\section{REFERENGES}

Domokos, L.; Pulay, Gy.; Petô, K. and Pongrácz, É. (2015): The Role of the State Audit Office of Hungary in Stabilising Public Finances. Public Finance Quarterly, Vol. 60, No. 4, pp. 415-432.

Domokos, L. and Holman, M. (2017): The Methogological Renewal of the State Audit Office of Hungary in Light of the Protection of Public Funds. Polgári Szemle/Civic Review, Vol. 13, Special Issue, pp. 83-98, https://doi.org/10.24307/psz.2017.0306.

Domokos, L.; Németh, E. and Jakovác, K. (2016): Supporting the Performance and Efficiency of Governance. Expediency Control and Performance Measurement in SAI's Audit. Public Governance Administration and Finance Law Review in the European Union and Central Eastern Europe, Vol. 1, No. 1, pp. 47-64.

Lentner, Cs. (2015): Uncertainty Factors in National Economy Planning. International Effects and Hungary's Outlook Up to 2050. Central European Political Science Review, Vol. 16, No. 62, pp. 9-26.

Lentner, Cs. (2017): Scientific Taxonomy of Hungarian Public Finances After 2010. Polgári Szemle/Civic Review, Vol. 13, Special Issue, pp. 21-38, https://doi.org/10.24307/psz.2017.0303.

Pulay, Gy.; Máté, J.; Németh, I. and Zelei, A. (2013): Budgetary Risks of Monetary Policy with Special Regard to the Debt Rule. Public Finance Quarterly, Vol. 58, No. 1, pp. 11-34.

Pulay, Gy.; Bagoly, B. and Gácser, J. (2015): Tanulmány a versenyképes tudás megszerzését és hasznosítását szolgáló állami intézkedések számvevốszéki ellenốrzése szempontjainak és fókuszterületeinek meghatározásához [Study on the determination of the criteria and focal areas of the State Audit Office's audits of government actions taken to acquire and utilise competitive knowledge]. State Audit Office of Hungary, https://asz.hu/ tanulmanyok-2015-ev.

Pulay, Gy.; Köllödné Gátai, M. and Vargha, B. (2016): Tanulmány az állam piacszervezô tevékenysége számvevốszéki ellenôrzése szempontjainak és fókuszterületeinek meghatározásához [Study for the determination of the criteria and focal areas of the State Audit Office's audits of the government's market organisation activity]. State Audit Office of Hungary, https://asz.hu/hu/tanulmanyok-2016-ev.

Pulay, Gy.; Szilágyi, G. A.; Balázs, M. and Jakab, L. (2017): A magyar kutatás-fejlesztés és innovációs tevékenység eredményessége [Efficiency of Hungairan research, development and innovation activity]. State Audit Office of Hungary, https://asz.hu/hu/tanulmanyok-2017-ev. 